ISSN1027-5495. Functional Materials, 25, No.1 (2018), p. 184-187

doi:https://doi.org/10.15407/fm25.01.184

(C) 2018 - STC “Institute for Single Crystals"

\title{
Electrochemical sensor for sulfide determinationin food additives
}

\author{
Jian Chu, Wentan Guo \\ Tianjin Key Laboratory of Information Sensing \& Intelligent Control, \\ Tianjin University of Technology and Education, Hexi, Tianjin, 300222, \\ China
}

Received December 21, 2017

\begin{abstract}
This study is devoted to using of electrochemical sensor based on multiwalled carbon nanotubenanogold composite membrane for detection of sulfite which is one of harmfull food additives. The experimental results demonstrated that the application of electrochemical sensor could improve electron transport rate and increase electrode surface and effective contact area of solution. Sulfite in dried bean milk cream in tight rolls could be effectively detected using voltammetric method. This work provides a reference for the application of electrochemical sensor in detection of food additives.

Keywords: electrochemical sensor, arbon nanotube-nanogold composite, food additives.
\end{abstract}

\begin{abstract}
Данное исследование посвящено использованию электрохимического датчика на основе многослойной углеродной нанотрубки - нанослойной композитной мембраны для обнаружения сульфита, который является одним из вредных пищевых добавок. Экспериментальные результаты показали, что применение электрохимического датчика может улучшить скорость переноса электронов и увеличить поверхность электрода и әффрективную площадь контакта с раствором. Проведенные исследования позволяют применение электрохимического датчика для определения наличия пищевых добавок.
\end{abstract}

Електрохімічний датчик для визначення сульфіда. Jian Chu, Wentan Guo.

Дане дослідження присвячене використанню електрохімічного датчика на основі багатошарової вуглецевої нанотрубки - нанослойной композитної мембрани для виявлення сульфіту, який є одним 3 шкідливих харчових добавок. Експериментальні результати показали, що застосування електрохімічного датчика може поліпшити швидкість перенесення електронів і збільшити поверхню електрода і ефективну площу контакту 3 розчином. Проведені дослідження дозволяють застосування електрохімічного датчика для визначення наявності харчових добавок.

\section{Introduction}

With the occurrence of events such as Sudan red and melamine in recent years, more attentions have paid to food additives. Food additives can effectively prevent food spoilage and extend quality guarantee period; however, excessive intake of food additives can cause severe damages to health. Therefore it is urgent to find approaches to efficiently detect food additives. For example sulfite which is very harmful has been extensively applied in different food processing steps such as preservation of fresh fruits, bacterial inhibition and oxidation resistance in the manufacture process of wines such as grape wine and browning prevention of aquatic products [1-5].To change the status of food safety, technologies for detecting food additives have become the key research subject in food safety field [6-10].

The purpose of this work is to study the capabilities of an electrochemical sensor to determine the additives of sulfite in food. 


\section{Experimental}

\subsection{Experimental preparation}

CHI650 electrochemical workstation was used. Glassy carbon (GC) electrode was taken as the working electrode. Reference electrode was Ag/AgCl. Counter electrode was spiral platinum wire. Dried bean milk cream in tight rolls was a tested material. $0.2 \mathrm{~mol} / \mathrm{L}$ phosphate buffer solution (PBS) was taken as supporting electrolyte. $0.2 \mathrm{~mol} / \mathrm{L}$ PBS was prepared by mixing $38 \mathrm{ml}$ of sodium dihydrogen phosphate solution $(0.2 \mathrm{~mol} / \mathrm{L})$ and $162 \mathrm{ml}$ of disodium hydrogen phosphate $(0.2 \mathrm{~mol} / \mathrm{L})$.Hydrochloric acid was prepared by diluting concentrated hydrochloric acid with equal amount of distilled water. Lead acetate was prepared by adding $4 \mathrm{~g}$ of Lead acetate to $200 \mathrm{ml}$ of water. Iodine standard solution was prepared by diluting calibrated iodine standard solution $(0.1 \mathrm{~mol} / \mathrm{L})$ with water whose amount was ten times that of iodine standard solution. Starch indicator solution was prepared as follows: $1 \mathrm{~g}$ of soluble starch was added with a little water. When it became mushy after stirring, $100 \mathrm{~mL}$ of boiling water was added slowing. Then the mixture was heated till boiling. After 3-min cooling, it was preserved for standby. Concentrated nitric acid was processed by refluxing treatment and then preserved for standby.

Synthesis of nano-gold

$50 \mathrm{~mL}$ of $\mathrm{HAuCl}_{4}$ solution whose concentration was $0.01 \%$ was prepared. Then obtained solution was heated till boiling. The boiled solution was processed by reflux condensation and then stirred. The solution was added with $1 \mathrm{~mL}$ of sodium citrate (1\%), followed by 40 -min stirring in boiling state. After the heating device was closed, stirring continued till the synthesized nano-gold colloid solution was cooled to room temperature. The obtained solution was refrigerated at $5{ }^{\circ} \mathrm{C}$.

Preprocessing of glassy carbon electrode

A GC electrode was polished by aluminium oxide. After three times of polishing, the GC electrode was processed by ultrasonic cleaning using 100\% ethyl alcohol and distilled water, 5 min each time. Then the electrode was dried.

\section{Preparation of modified electrode}

$2 \mathrm{mg}$ of the prepared concentrated nitric acid was dispersed using $2 \mathrm{~mL} \mathrm{~N}, \mathrm{~N}$ - dimethylformamide. After dispersion, $2 \mathrm{~mL}$ of nanogold solution was added. $6 \mu \mathrm{L}$ of suspension was taken and droped on the surface of the GC electrode. Then the electrode was dried under an infrared lamp. After drying, $5 \mu \mathrm{L}$ of ethanol solution was dropped on the surface of the electrode to vaporize the solution.
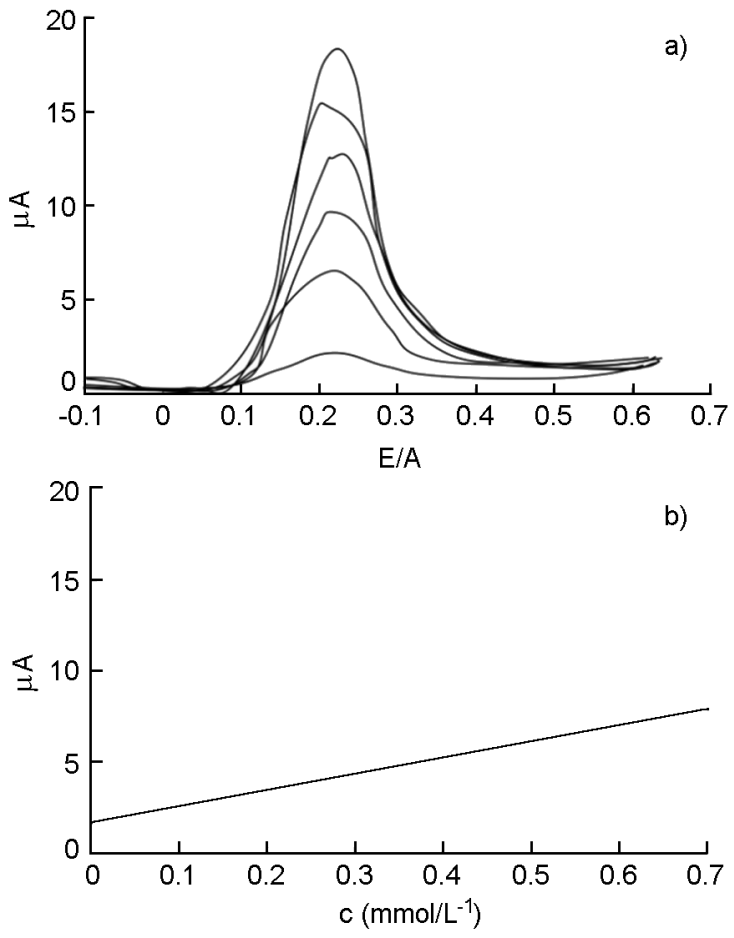

Fig. 1. The differential pulse voltammetry curves for the electrode in sulfite

\section{Test method}

A small quantity of the solution was put into an electrolysis cup along with PBS $(0.2 \mathrm{~mol} / \mathrm{L})$. Then cyclic voltammetry scan was performed using $0-1.0 \mathrm{~V}$ potential window; ${ }^{11}$ the scanning frequency was set as $0.05 \mathrm{~V} / \mathrm{s}$. Differential pulse voltammetry was performed using $0.1-1.0 \mathrm{~V}$ potential window; [12] the potential increment was set as $0.01 \mathrm{~V}$, the impulse amplitude was set as $0.05 \mathrm{~V}$, and the pulse superposition was set as $0.04 \mathrm{~V}$. The experimental results were recorded during experiment. The experimental temperature was kept at $27^{\circ} \mathrm{C}$.

Preprocessing of samples

$10 \mathrm{~g}$ of dried bean milk cream in tight rolls was pounded to pieces and then transferred to a $50 \mathrm{ml}$ centrifuge tube. $40 \mathrm{~mL}$ of normal propyl alcohol (2\%) was added to stabilize the dried bean milk cream in tight rolls. The stabilized solution was centrifuged at $6000 \mathrm{r} / \mathrm{min}$ and 5 ${ }^{\circ} \mathrm{C}$ for $20 \mathrm{~min}$. The supernatant liquid was filtrated using double-layer filter paper. Then $2 \%$ normal propyl alcohol solution was added till the volume of the solution became $50 \mathrm{ml}$. Then it was preserved.

\section{Results and discussion}

Electrode linearity and detection limit

Figure 1 and 2 show the differential pulse voltammetry curves for the electrode in sulfite and sodium formaldehyde sulfoxylate at different concentrations. Figure 1 demonstrates that 

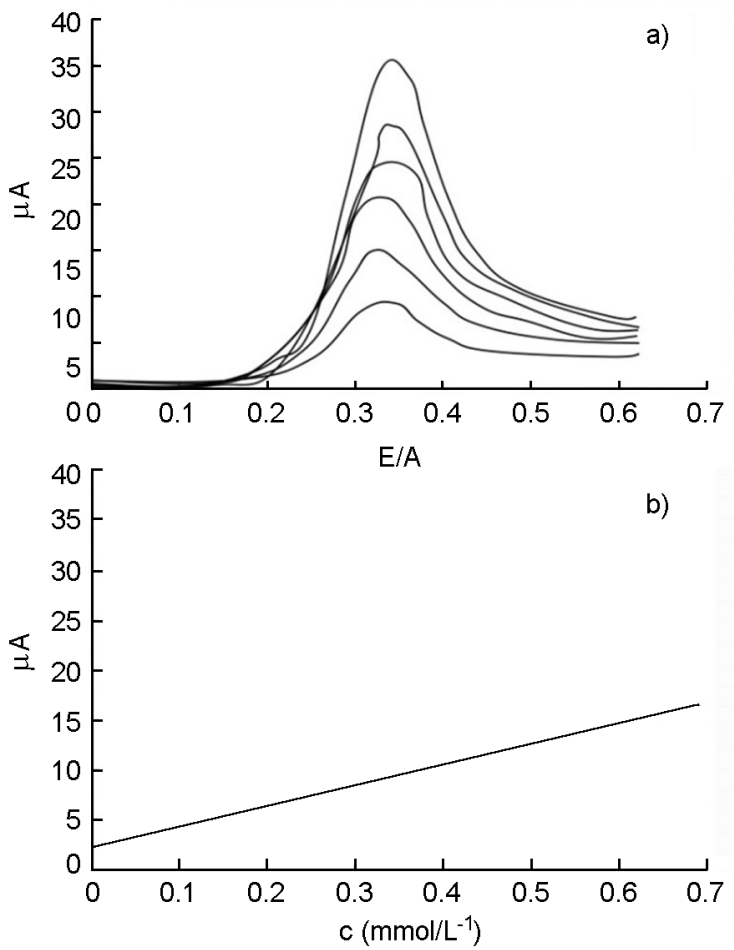

Fig. 2. The differential pulse voltammetry curves for the electrode in sodium formaldehyde sulfoxylate

the response potential of the electrode in sulfite was $0.2 \mathrm{~V}$, and it increased with the increase of the concentration of sulfite; there was a good linear relationship when the concentration was $0.08 \sim 0.7 \mathrm{mmol} / \mathrm{L}$. The linear equation was $x=0.595+11.543 \times 10^{3} \mathrm{c}$, and the lowest detection concentration was $5 \times 10^{-5} \mathrm{~mol} / \mathrm{L}$. Figure $2 \mathrm{dem}$ onstrated that the electrode had a favorable catalysis response to sodium formaldehyde sulfoxylate, catalysis potential was $0.35 \mathrm{~V}$, and there was a good linear relationship between oxidation peak current and the concentration of sodium formaldehyde sulfoxylate when the concentration of sodium formaldehyde sulfoxylate was between $0.06 \mathrm{mmol} / \mathrm{L}$ and $0.7 \mathrm{mmol} / \mathrm{L}$. The linear equation was $x=1.568+21.269 \times 10^{3} \mathrm{c}$, the lowest detection concentration was $3 \times 10^{-5} \mathrm{~mol} / \mathrm{L}$.

Stability of electrode

The stability and electrochemical behaviors of the electrode surface and the reproducibility of electro-catalytic behaviors were tested using differential pulse voltammetry. The experimental results demonstrated that the relative standard deviation of peak current signals of the mixed solution of nitrite and sodium formaldehyde sulfoxylate $(1.0 \mathrm{mmol} / \mathrm{L})$ detected with ten developed electrical machineries under the same conditions was smaller than $7.7 \%$, suggesting the favorable reproducibility of the prepared electrode. Then the mixed solution of sulfite and sodium formaldehyde sulfoxylate $(1.0 \mathrm{mmol} / \mathrm{L})$ was scanned with one electrode for ten times, and the relative standard deviation was $2.5 \%$.

Test results of samples

In the test, dried bean milk cream in tight rolls was added to sulfite and sodium formaldehyde sulfoxylate in a dose of $100 \mathrm{mg} / \mathrm{kg}$ to test the recycle rate of sulfite and sodium formaldehyde sulfoxylate. The results when standard was added and not added are shown in Table 1.

Table 1 demonstrates that sodium formaldehyde sulfoxylate was not detected out in the samples. In the experiment of recovery of sample addition, the recovery rates of sulfite and sodium formaldehyde sulfoxylate were both about $90 \%$. It revealed that the electrochemical sensor could effectively detect sulfite in the dried bean milk cream in tight rolls.

To sum up, there was a good linear relationship when the concentration of sulfite was be-

Table 1 - The detection results of sulfite and sodium formaldehyde sulfoxylate in the dried bean milk cream in tight rolls

\begin{tabular}{|c|c|c|c|c|c|}
\hline \multirow{3}{*}{$\begin{array}{c}\text { Addition } \\
\text { amount } \\
\mathrm{mg} / \mathrm{kg}\end{array}$} & & \multicolumn{2}{|c|}{ Sample a } & \multicolumn{2}{|c|}{ Sample b } \\
\hline & Sulfite & I & 100 & I & 100 \\
\hline & $\begin{array}{l}\text { Sodium formalde- } \\
\text { hyde sulfoxylate }\end{array}$ & I & 100 & I & 100 \\
\hline \multirow{2}{*}{$\begin{array}{c}\text { Measured value } \\
\mathrm{mg} / \mathrm{kg}\end{array}$} & Sulfite & $136.4 \pm 5.6$ & $229.6 \pm 1.8$ & $86.5 \pm 3.8$ & $176.5 \pm 3.1$ \\
\hline & $\begin{array}{l}\text { Sodium formalde- } \\
\text { hyde sulfoxylate }\end{array}$ & N.D & $95.3 \pm 3.1$ & N.D & $87.5 \pm 3.5$ \\
\hline \multirow{2}{*}{$\begin{array}{c}\text { Recovery rate } \\
\%\end{array}$} & Sulfite & I & 94.2 & I & 91.3 \\
\hline & $\begin{array}{l}\text { Sodium formalde- } \\
\text { hyde sulfoxylate }\end{array}$ & I & 94.1 & I & 90.2 \\
\hline
\end{tabular}


tween $0.08 \mathrm{mmol} / \mathrm{L}$ and $4 \mathrm{mmol} / \mathrm{L}$, and the lowest detection concentration was $5 \times 10^{-5} \mathrm{~mol} / \mathrm{L}$; there was a good linear relationship when the concentration of sodium formaldehyde sulfoxylate was between $0.06 \mathrm{mmol} / \mathrm{L}$ and $5.0 \mathrm{mmol} /$ $\mathrm{L}$, and the lowest detection concentration was $3 \times 10^{-5} \mathrm{~mol} / \mathrm{L}$. The detection results demonstrated that the recovery rates of sulfite and sodium formaldehyde sulfoxylate were $91.3 \%$ and $90.2 \%$ respectively.

\section{Conclusion}

Sulfite as a kind of food additive has been extensively added to food as a preservative; however it can harm human body. Excessive intake of sulfite can affect health of human body. In this study, N-dimethylformamide was dispersed to multi-walled carbon nanotube and then modified on a glassy carbon electrode. The developed electrochemical sensor was used to test dried bean milk cream in tight rolls. The electrochemical sensor suggested a favorable stability and reproducibility. Moreover the electrochemical sensor could detect sulfite and sodium formaldehyde sulfoxylate simultaneously. This work provides a reference for the application of electrochemical sensor in food detection.

\section{Acknowledgement}

This study was supported by Research on a new method for measuring moisture content of starch (KJ1730).

\section{References}

1. G.S. Wang, M.H. Yu, J.Y. Zhu, Adv. Mater. Res., 236, 173, 2011.

2. M. Mancin, M. Toson, M. Grimaldi, et al., Accredit. Qual. Assur., 20, 255, 2015.

3. K.L.B. Solis, G.U. Nam, Y. Hong, Environm. Chem., 14, 2017.

4. K. Higashi, Y. Okamoto, T. Mano, et al., Jpn Soc. Food Chem., 21, 187, 2017.

5. A.M. Szema, S.A. Hamidi, A. Koller, et al., BMC Immunol., 12, 66, 2011.

6. M. Carocho, P. Morales, I.C.F.R. Ferreira, Trends Food Sci. Tech., 45, 284, 2015.

7. I.J. Skypala, M. Williams, L. Reeves, et al., Clin. Translat. Allergy, 5, 34, 2015.

8. E. Takeda, H. Yamamoto, H. Yamanaka-Okumura, Y. Taketani, Adv. Nutrit., 5, 92, 2014.

9. M. Zhang, H. Cai, J.L. Shen, Spectrosc. Spect. Anal., 31, 1809, 2011.

10. E. Peycheva, R. Alexandrova, G. Miloshev, LWT - Food Sci. Tech., 59, 510, 2014.

11. L. Demarconnay, E. Raymundo-Piñero, F. Béguin, J. Power Sources, 196, 580, 2011.

12. Ø. Mikkelsen, K.H. Schrøder, Electroanalysis, 13, 687, 2015 . 